\title{
Metode Batik sebagai Upaya Membumikan Budaya Masyarakat Pesisir dalam Pembelajaran Bahasa Indonesia di Pekalongan
}

\author{
Erwan Kustriyono \\ Program Studi Pendidikan Bahasa dan Sastra Indonesia \\ FKIP, Universitas Pekalongan
}

Corresponding email: erwan.unikal@gmail.com

\begin{abstract}
Coastal communities are synonymous with sea and coast, in general, income from seafood and tourism. The education sector becomes a homework for the regional government to develop. Likewise, coastal communities in the city of Pekalongan, they still think the same as coastal communities in general. Then the right method or technique is needed in learning activities. The very basic method that must be introduced to coastal communities is BATIK learning (read, write and work). The BATIK method was introduced in the community, both at universities, high schools and elementary schools. This simple method can foster a literacy culture in the Pekalongan City community which is generally located on the coast of North Coast of Central Java. The Batik Method was introduced in Indonesian language learning in schools and universities. The purpose of this article is to describe the interest in learning of students and students in the Pekalongan City, introducing the BATIK method in learning (especially Indonesian) to students and students in the Pekalongan City. The research method uses the case study method. Data collection techniques using observation, interviews, and documentation. The data analysis method uses the flow model. Data validity test uses triangulation test. The results showed that interest in learning especially Indonesian in Pekalongan City was still low, evidently the interest in reading, writing and making works was still low. The most appropriate and simple solution to arouse interest in learning Indonesian with the BATIK method (read, write and work).
\end{abstract}

Keywords: Batik Method, Indonesian Language, and Coastal Society

\begin{abstract}
Abstrak
Masyarakat pesisir identik dengan laut dan pantai, pada umumnya berpenghasilan dari hasil laut dan pariwisata. Bidang pendidikan menjadi pekerjaan rumah bagi pemerintah daerah untuk dikembangkan. Begitu pula masyarakat pesisir di Kota Pekalongan, mereka masih beranggapan sama dengan masyarakat pesisir pada umumnya. Maka diperlukan metode atau teknik yang tepat dalam kegiatan pembelajaran. Metode sangat dasar yang harus dikenalkan kepada masyarakat pesisir adalah pembelajaran BATIK (baca, tulis dan karya). Metode BATIK mulai dikenalkan di masyarakat, baik di universitas, sekolah menengah, dan sekolah dasar. Metode sederhana ini dapat menumbuhkan budaya literasi di masyarakat Kota Pekalongan yang pada umumnya berada di pesisir Pantai Utara Jawa Tengah. Metode Batik dikenalkan
\end{abstract}


dalam pembelajaran bahasa Indonesia di sekolah dan universitas. Tujuan dari artikel ini adalah mendeskripsikan minat belajar siswa dan mahasiswa di Kota Pekalongan, mengenalkan metode BATIK dalam pembelajaran (khususnya bahasa Indonesia) pada siswa dan mahasiswa di Kota Pekalongan. Metode penelitian menggunakan metode studi kasus. Teknik pengumpulan data menggunakan teknik observasi, wawancara, dan dokumentasi. Metode analisis data menggunakan model alir. Uji keabsahan data menggunakan uji triangulasi. Hasil penelitian menunjukkan bahwa minat belajar khususnya bahasa Indonesia di Kota Pekalongan masih rendah, terbukti minat membaca, menulis, dan membuat karya masih rendah. Solusi paling tepat dan sederhana untuk membangkitkan minat belajar bahasa Indonesia dengan metode BATIK (baca, tulis dan karya).

Kata kunci: Metode Batik, Bahasa Indonesia, dan Masyarakat Pesisir

\section{PENDAHULUAN}

Budaya dan karakteristik masyarakat Pekalongan yang memiliki sejarah panjang terhadap kemaritiman di Indonesia. Masyarakat Pekalongan juga memiliki sejarah panjang tentang budaya dan pendidikan masyarakatnya. Kota pekalongan dikenal dengan kota pesisir, serta memiliki budaya yang kuat dalam sektor perdagangan. Hasil budaya yang sangat nyata dalam bidang perdangang adalah bagaimana ciri khas dari kain batik di Kota Pekalongan. Masyarakat Pekalongan memiliki budaya perdangan yang kuat, selain itu sangat kental nilai agama (religiusitas) di masyarakat. Dengan budaya yang demikian, maka Pekalongan di kenal dengan akulturasi budaya dari Arab, Jawa dan Tionghoa (China). Sejalan dengan pendapat tersebut Agus (2018:1) ada tiga dimensi budaya yang ada di Pekalongan yang sangat kental menjadi satu kesatuan dalam kehidupan masyarakat yang saling toleransi. Tiga dimensi budaya tersebut adalah budaya Jawa, Arab dan Tionghoa. Keberagamanan budaya dan etnis tersebut menjadikan budaya masyarakat yang unik dan beragam pula.

Pekalongan dikenal dengan masyarakat yang majemuk, maka di kenal dengan istilah di masyarakat ada kampung Arab, Kampung China (Tionghoa), dan kampung Jawa (yang dihuni oleh masyarakat pada umumnya). Mereka semua menekuni kegiatan yang sama, yaitu dalam sektor perniagaan (perdagangan). Sebagia dari masyarakat Pekalongan ada juga yang menjadi nelayan, yang menajadi ciri khas masyarakat pesisir. Adapula yang menekuni sektor pariwisata dan kuliner khas Pekalongan. Berbagai macam profesi ini menjadi keunikan budaya tersendiri di Pekalongan. Sehingga Pekalongan mendapat julukan Kota Kreatif Dunia oleh UNESCO. Dengan label kota kreatif ini maka Pekalongan terus berbenah dari berbagai macam sektor, baik dari masyarakat dan pemerintah saling bersinergi. Fokus yang akan diangkat dalam artikel ini adalah dalam sudut pandang pendidikan, khususnya lagi dalam bidang pembelajaran bahasa.

Pendidikan menjadi sektor yang masih lemah dan harus di dorong untuk terus maju di Kota Pekalongan. Menurut Badan Pusat Statistik Kota Pekalongan (2016:90) peningkatan partisipasi masyarakat dalam dunia pendidikan harus diimbangi dengan penyediaan sarana pendidikan dan pendidik oleh pemerintah Kota Pekalongan. Selaian sarana pendidikan, pemerintah harus fokus dalam sektor pendidik. Pendidik harus memiliki kemampuan dalam membangkitkan minat dan motivasi siswa dalam 
belajar. Selain itu, pendidik harus mampu menerapkan metode atau teknik yang tepat dalam pembelajaran. Pada artikel ini akan fokus dalam pembelajaran bahasa Indonesia. Bagaimana peran guru atau pendidik bahasa Indonesia dalam membantu pemerintah Kota Pekalongan dalam mewujudkan Gerakan Literasi Sekolah (GLS). Peran guru bahasa Indonesia dalam mewujudkan GLS di Sekolah Dasar, Sekolah Menengah Pertama, Sekolah Menengah Atas dan gerakan literasi ini dilanjutkan di perguruan tinggi atau universitas.

Gerakan Literasi Sekolah (GLS) adalah sebuah gerakan dalam upaya menumbuhkan budi pekerti siswa yang bertujuan agar siswa memiliki budaya membaca dan menulis sehingga tercipta pembelajaran sepanjang hayat (Disdik Bandung, 2017:1). Kegiatan rutin ini dilaksanakan dengan tujuan untuk menumbuhkan minat baca peserta didik dalam upaya meningkatkan keterampilan membaca siswa dan masyarakat. Peran guru dan dosen bahasa Indonesia diperlukan untuk mewujudkan budaya ini di Kota Pekalongan. pembelajaran bahasa Indonesia di sekolah masih mengggunakan metode atau teknik pembelajaran yang tradisional, walaupun di sekolah sudah mengenal kurikulum baru dengan nama kurikulum 2013 (kurtilas atau K-13). Kurikulum ini menggunakan pendekatan scientific approach. Seharusnya guru bahasa Indonesia sudah menggunakan metode atau teknik yang tepat dalam kegiatan pembelajaran bahasa Indonesia. Hal ini sesuai pendapat Noermanzah (2015:274) bahwa guru bahasa Indonesia berperan dalam menciptakan metode pembelajaran yang memberikan pengalaman belajar yang kreatif dan berpikir kritis sehingga dapat mencapai tujuan pembelajaran yang diharapkan kurikulum.

Metode atau teknik yang tepat yang digunakan dalam pembelajaran bahasa Indonesia di sekolah dasar (SD), sekolah menengah (SMP, SMK, dan SMA), serta perguruan tinggi atau universitas akan membantu mempermudah dalam mendukung gerakan literasi di masyarakat. Metode dalam pembelajaran bahasa Indonesia tidak boleh meninggalkan akar tradisi dalam pembelajaran bahasa Indonesia, yaitu kegiatan atau literasi dasar yaitu kegiatan membaca. Keterampilan atau kegiatan membaca merupakan awal dari gerakan literasi. Pintu dalam membuka minat dan motivasi dalam belajar adalah dengan kegiatan membaca. Guru dan siswa yang memiliki keterampilan dasar membaca. Sejalan dengan pendapat tersebut, menurut Abidin, dkk., (2017:1) secara tradisional, literasi dipandang sebagai kemampuan membaca dan menulis. Orang yang dapat dikatakan lietarat dalam pandangan ini adalah orang yang mampu membaca dan menulis atau bebas buta huruf. Salah satu yang menjadi titik tumpu dari literirasi adalah keterampilan membaca.

Selain keterampilan membaca, diperlukan keterampilan menulis. Keterampilan menulis sebagai kegiatan atau keterampilan berbahasa yang bersifat produktif dengan cara menuangkan gagasan ke dalam representasi grafis atau tertulis sehingga memberikan pemahaman kepada pembaca tentang pesan yang disampaikan (Noermanzah, 2018:116). Keterampilan menulis merupakan wujud manifestasi dari kegiatan membaca. Keterampialn menulis ini harus dimiliki oleh siswa di berbagai jenjang sekolah yang ada di Kota Pekalongan. Keterampilan menulis harus dimilki siswa dari jenjang sekolah dasar hingga perguruan tinggi. Sebagai upaya dalam membangkitkan minat menulis siswa diperlukan metode atau teknik yang tepat, selain itu harus menggunaka bahan ajar yang tepat. Bahan ajar yang tepat ini dapat digunakan dalam kegiatan membaca, kemudian berlanjut dalam kegiatan menulis. Maka diperlukan pendidik atau guru bahasa Indonesia yang kreatif. Guru dapat memanfaatkan bahan bacaan yang ada dan dekat dengan siswa 
atau mahasiswa. Bahan ajar tersebut dapat berupa buku sejarah Kota Pekalongan, atau bahan bacaan yang berhubungan dengan Pekalongan, sehingga membangkitkan minat membaca, serta dapat merangsang untuk menulis.

Tulisan yang dihasilkan oleh siswa dan mahasiswa tersebut harus ada wadah yang jelas. Maka harus disebut atau dibuat dalam bentuk karya, dapat berupa esai, cerpen, novel, atau laopran observasi, dapat pula disebut karangan, dan laporan perjalanan. Pada intinya siswa dan mahasiswa dapat menuangkan ide hasil dari kegiatan membaca dalam bentuk tulisan. Tulisan tersebut dibingkai menjadi karya atau hasil yang dapat dinikmati atau dibaca oleh orang lain. Bahan bacaan tersebut dapat menggunakan buku berupa budaya dan cerita sejarah tentang Pekalongan, sehingga dapat menumbuhkan minat baca dan menulis siswa dan mahasiswa. Berdasarkan gambaran tersebut, maka artikel ini memunculkan tema pembahasan "Metode Batik sebagai Upaya Membumikan Budaya Masyarakat Pesisir dalam Pembelajaran Bahasa Indonesia di Pekalongan". Masalah atau tema yang akan dibahas dalam artikel ini dari artikel ini adalah bagaiamana minat belajar bahasa Indonesia siswa dan mahasiswa di Kota Pekalongan dalam mewujudkan gerakan literasi dan bagaimana mengenalkan metode BATIK (baca, tulis, dan karya) dalam pembelajaran (khususnya bahasa Indonesia) pada siswa dan mahasiswa di Kota Pekalongan.

\section{METODE}

Metode yang digunakan dalam artikel ini menggunakan penelitian kualitatif, jenis penelitian kualitatif studi kasus di sekolah Dasar (SD) di Kota Pekalongan, Sekolah Menengah (SMP dan SMA) di Pekalongan dan Universitas Pekalongan. Sumber data menggunakan kegiatan pembelajaran pelajaran bahasa Indonesia dan mata kuliah bahasa Indonesia. Teknik pengumpulan data menggunakan teknik observasi, wawancara, dan dokumentasi. Data Penelitian dalam artikel ini adalah hasil pengamatan dan wawancara guru, siswa dan mahasiswa pada saat pelajaran dan mata kuliah bahasa Indonesia. Metode analisis data menggunakan model alir. Fokus dalam penelitian ini adalah mengetahui minat dan metode yang tepat dalam pembalajaran bahasa Indonesia. Uji keabsahan data menggunakan uji triangulasi dari berbagai sumber data penelitian yang diperoleh dari observasi atau pengamatan, wawancara, dan dokumentasi.

\section{HASIL}

1. Minat Belajar Bahasa Indonesia Siswa dan Mahasiswa di Kota Pekalongan dalam Mewujudkan Gerakan Literasi

Minat belajar khususnya bahasa Indonesia di Kota Pekalongan masih rendah, terbukti minat membaca, menulis dan membuat karya masih rendah. Setelah melakukan kegiatan pengamatan dan wawancara di sekolah dan perguruan tinggi, minat membaca siswa dan mahasiswa di Kota Pekalongan masih rendah. Hal ini disebaban oleh budaya masyarakat pesisir yang identik dengan nelayan dan perdagangan. Selain itu sarana dan prasarana membaca masih kurang di lemabaga pendidikan seperti ketersediaan perpustakaan, bahan bacaan (buku), ruang baca yang representatif, serta komunitas baca yang masih langka atau jarang. Minat menulis siswa dan mahasiswa juga masih rendah hal ini dilihat dari tulisan siswa dan mahasiswa masih belum banyak dihasilkan dan dipublikasikan. Selain itu, belum ada karya siswa dan mahasiswa di kota Pekalongan yang sederhana dapat dinikmati 
oleh orang lain dan masyarakat. Hal ini perlu ditindak lanjuti oleh guru dan dosen khususnya yang mengampu pelajaran dan mata kuliah bahasa Indonesia.

2. Metode BATIK (Baca, Tulis, dan Karya) dalam Pembelajaran (Khususnya Bahasa Indonesia) pada Siswa dan Mahasiswa di Kota Pekalongan

Metode BATIK (baca, tulis, dan karya) dapat meningkatkan minat siswa dan mahasiswa untuk belajar bahasa Indonesia, dengan menggunakan dan mengenalkan budaya masayarakat pesisir khususnya Pekalongan siswa dan mahasiswa tertarik untuk membaca dan menulis tentang Pekalongan. Tulisan tersebut dapat berupa karya esai, karangan bebas, laporan observasi, laporan perjalanan, cerpen, dongeng, dan cerita rakyat. Hasil karya peserta didik ini dipublikasikan dengan baik oleh guru dan dosen sebagai bahan ajar dalam pembelajaran, sehingga siswa dan mahasiswa tertarik untuk melakukan kegiatan BATIK (baca, tulis dan karya) dalam pembelajaran bahasa Indonesia. Sehingga mendukung terwujudnya Gerakan Literasi Sekolah (GLS).

\section{PEMBAHASAN}

1. Minat Belajar Bahasa Indonesia Siswa dan Mahasiswa di Kota Pekalongan dalam Mewujudkan Gerakan Literasi

Peran pendidik (guru dan dosen) dalam menumbuhkan minat dan motivasi siswa dan mahasiswa dalam belajar sangat penting. Hal ini sesuai dengan pendapat Noermanzah (2015:274) bahwa guru bahasa Indonesia berperan dalam menciptakan metode pembelajaran yang memberikan pengalaman belajar yang kreatif dan berpikir kritis sehingga dapat mencapai tujuan pembelajaran yang diharapkan kurikulum 2013. Pengalaman belajar yang kreatif dan berpikir kritis ini tentu akan meningkatkan minat dan motivasi siswa untuk belajar bahasa Indonesia. Minat dan motivasi ini akan membuka cakrawala pengetahuan siswa dan mahasiswa dalam kegiatan pembelajaran sehari-hari. Minat yang baik akan mempermudah pendidik dalam mengembangkan dan memperluas pengetahuan siswa dan mahasiswa. Dengan gambaran yang demikian, maka pendidik harus menumbuhkan minat siswa dan mahasiswa dalam belajar. Dalam artikel ini memberikan fokus kajian dalam pembelajaran bahasa Indonsia, baik di sekolah dan perguruan tinggi.

Kota Pekalongan memiliki wilayah yang idak begitu luas, terdiri hanya empat kecamatan. Kota Pekalongan memiliki budaya dan karakteristik yang unik. Masyarakat Pekalongan pada umumnya mengutamakan perdagangan dan UMKM. Dengan budaya masyarakat yang demikian menjadikan masyarakat Pekalongan memiliki minat yang tidak begitu tinggi dalam dunia pendidikan. Selain itu, beberapa sekolah dan sarana pendidikan di Pekalongan sampai saat ini masih terdampak bencana rob yang berkepanjangan. Hal ini menambah pelik variabel minat siswa dan mahasiswa dalam belajar, khususnya belajar bahasa Indonesia.

Minat belajar bahasa Indonesia di Kota Pekalongan masih rendah. Mencermati kompetensi inti yang bahasa Indonesia di Sekolah Dasar minat membaca siswa masih rendah. Rendahnya minat baca siswa SD ini dibuktikan saat kegiatan wawancara dan observasi di SD dengan guru dan siswa didapatkan bahwa minat mereka dalam membaca masih rendah. Siswa diminta untuk membaca buku secara mandiri masih sangat sulit untuk diterapkan. Minat membaca siswa SD kurang disebabkan juga oleh sarana dan prasarana pembelajaran di SD belum lengkap. Kelengkapan sarana prasana perpustakaan sekolah, di SD hanya memiliki satu perpustakaan. Perpustakaan tersebut tidak memiliki buku referensi yang 
lengkap. Salah satu buku yang belum dimiliki perpustakaan adalah buku berkaitan dengan sejarah dan budaya pekalongan. jika dicermati KD yang muncul dalam kurikulum SD bahasa Indonesia memunculkan keterampilan membaca dan menulis sejak SD kelas IV sampai kelas VI. Dengan gambaran demikian, diperlukan metode yang tepat dalam menumbuhkan minat siswa dalam membaca dan menulis dengan mengedepankan budaya lokal Kota Pekalongan atau masyarakat pesisir pekalongan.

Materi yang muncul dalam kurikulum yang ada di SMP sudah meminta siswa untuk membaca juga dengan mandiri. Siswa SMP yang ada di Kota Pekalongan harusnya sudah memiliki wawasan bahasa dan sastra yang ada di sekitar siswa. Artikel ini belum menemukan minat dan budaya yang baik di keterampilan membaca dan menulis. Siswa SMP Kota Pekalongan belum memiliki minat dalam membaca, rendahnya minat ini dikarenakan peran guru yang belum aktif dan bahan bacaan yang masih belum memenuhi standar. Maka diperlukan peran aktif guru dalam membangkitkan minat membaca siswa sehingga apabila minat membaca meningkat, diharapkan minat menulis dan berkarya siswa SMP juga meningkat pula. Selain itu, perbaikan sarana dan prasarana yang diperlukan untuk kemajuan perpustakaan sekolah perlu dikembangkan dan dipenuhi.

Minat belajar bahasa Indonesia di SMA Kota Pekalongan sudah lebih baik dibandingkan SD dan SMP. Penelitian yang dilakukan oleh tim PKM mahasiswa Universitas Pekalongan tahun 2018 minat membaca siswa SMA di Kota Pekalongan dari data yang masuk lebih dari 60\% siswa SMA sudah memiliki minat baca yang cukup baik (Eryanto, dkk., 2018:8). Minat membaca ini didukung oleh pendekatan, metode dan motivasi guru untuk membangkitkan minat membaca siswa. Selain itu, sekolah bersama perpustakaan memfasilitasi siswa SMA untuk mengakses buku diperpustakaan. Sekolah mencoba melengkapi koleksi buku berkaitan dengan budaya masyarakat pesisir khususnya budaya masyarakat Pekalongan. Pemenuhan koleksi buku ini dapat meningkatkan minat baca di SMA. Namun, minat baca yang sudah baik ini belum diimbangi keterampilan menulis di SMA, sehingga belum menghasilkan karya yang baik dihasilkan oleh siswa SMA.

Pembelajaran bahasa Indonesia di Universitas di Kota Pekalongan masih rendah. Mahasiswa belum memiliki minat dalam membaca buku yang ada universitas. Berdasrkan hasil penelitian yang dilakukan oleh Kustriyono, dkk. tahun 2018 didapatkan bahwa mahasiswa di Universitas Pekalongan belum memiliki minat membaca yang baik (Kustriyono, dkk. 2018:17). Masih rendahnya minat baca ini disebabkan oleh metode atau teknik mengajar dosen bahasa Indonesia yang masih menggunakan metode yang tradisional atau ceramah. Selain itu, perpustkaan universitas belum mampu memenuhi sumber bacaan dan sumber referensi yang lengkap yang dibutuhkan oleh mahasiswa. Minat baca mahasiswa masih rendah, sehingga minat menulis masih rendah. Maka dapat disimpulkan bahwa minat belajar khususnya bahasa Indonesia di kota Pekalongan masih rendah, terbukti minat membaca, menulis dan membuat karya masih rendah.

2. Metode BATIK (Baca, Tulis, dan Karya) dalam Pembelajaran (Khususnya Bahasa Indonesia) pada Siswa dan Mahasiswa di Kota Pekalongan

Guru memiliki peran yang besar dalam menumbuhkan pembelajaran bahasa Indonesia yang baik. Dengan menggunakan metode BATIK (baca, tulis dan karya) pembelajaran bahasa Indonesia di SD dalam kurikulum 2013 akan membawa siswa memiliki kemampuan membaca dan menulis yang baik. Siswa SD dikenalkan bahan 
bacaan yang sederhana. Bahan bacaan ini dapat berupa budaya dan sejarah masyarakat pesisir khususnya Pekalongan. Pada dokumen kurikulum SD kompetensi dasar yang ada memunculkan karya berupa hasil identifikasi tokoh-tokoh di Pekalongan, ada teks narasi, menyerap informasi dari buku teks, serta membaca dan menghasilkan teks sastra berupa puisi. Karya ini dapat terinspirasi dari cerita, budaya, dan sejarah kota atau masyarakat Pekalongan.

Metode BATIK tepat diterakan di dalam pembelajaran SMP. Guru dan siswa bekerja sama dengan baik untuk menghasilkan dan mengembangkan budaya membaca dan menulis dalam kegiatan belajar mengajar. Jika minat membaca dan menulis sudah baik, maka diperlukan sarana berupa karya yang baik. Karya ini dihasilkan oleh siswa SMP dari hasil kegiatan membaca dan menulis. Siswa diberi bahan bacaan yang berkaitan dengan budaya dan karakteristik masyarakat Pekalongan. Metode BATIK akan membuka cakrawala siswa SMP dalam belajar bahasa Indonesia menjadi beragam, sehingga tertarik untuk mendalami bahasa Indonesia (baca dan tulis). Karya siswa SMP dapat berupa cerita imajinasi, rangkuman teks sastra dan nonsastra, menghasilkan teks eksplanasi, menghasilkan karya dalam bentuk cerpen datau cerita rakyat yang memiliki ciri khas Kota Pekalongan.

Siswa SMA di Kota Pekalongan sudah memilki minat yang cukup baik dalam kegiatan membaca. Keterampilan membaca ini didukung oleh etos guru yang baik serta didukung akses bacaan yang terjangkau yang disediakan oleh sekolah. Metode BATIK akan lebih meningkatkan minat membaca dan menulis siswa SMA di Kota Pekalongan. Didukung keterampilan berkarya, keterampilan ini dimunculkan untuk mendukung muara dari kegiatan membaca dan menulis. Karya yang dihasilkan oleh siswa SMA harusnya dapat dicetak atau diterbitkan dengan baik, sehingga dapat dibaca masyarakat atau siswa SMA lainnya. Siswa SMA dapat menghasilkan karya berupa cerita rakyat, kumpulan puisi, cerpen, ulasan buku, hingga menghasilkan novel. Karya siswa ini dapat terwujud apabila guru di SMA bersedia menerapkan metode BATIK dalam pembelajaran bahasa Indonesia, dengan bantuan buku atau bacaan yang memiliki muatan budaya pesisir atau masyarakat Pekalongan.

Mahasiswa di Pekalongan harus memiliki karya dalam kegiatan perkuliahan bahasa Indonesia. Penerapan metode BATIK dapat diterapkan dalam perkuliahan bahasa Indonesia. Dengan menggunakan bahan bacaan yang ada di perpustakaan khususnya bacaan yang berhubungan dengan budaya dan asal usul Kota Pekalongan. Mahasiswa diminta untuk menulis dalam bentuk cerita rakyat yang ada di lingkungan sekitar mahasiswa. Cerita rakyat tersebut kemudian di buat dalam bentuk buku dan dipublikasikan dan diajukan ISBN melalui lembaga press Universitas. Selain cerita rakyat, mahasiswa juga bias membuat bacaan berupa dongeng yang nantinya akan diterbitkan oleh universitas. Maka penerapan metode BATIK (baca, tulis dan karya) dapat diterapkan di Universitas Pekalongan. Metode BATIK (baca, tulis dan karya) dapat meningkatkan minat siswa dan mahasiswa untuk belajar bahasa Indonesia, dengan menggunakan dan mengenalkan budaya masayarakat pesisir khususnya Pekalongan siswa dan mahasiswa tertarik untuk membaca dan menulis tentang Pekalongan sehingga mendukung terwujudnya Gerakan Literasi Sekolah (GLS). 


\section{KESIMPULAN DAN SARAN}

Minat belajar khususnya bahasa Indonesia di Kota Pekalongan masih rendah, terbukti minat membaca, menulis dan membuat karya masih rendah. Setelah melakukan kegiatan pengamatan dan wawancara di sekolah dan perguruan tinggi, minat membaca siswa dan mahasiswa di Kota Pekalongan masih rendah. Hal ini disebaban oleh budaya masyarakat pesisir yang identik dengan nelayan dan perdagangan. Selain itu sarana dan prasarana membaca masih kurang di lemabaga pendidikan seperti ketersediaan perpustakaan, bahan bacaan (buku), ruang baca yang representatif, serta komunitas baca yang masih langka atau jarang. Minat menulis siswa dan mahasiswa juga masih rendah hal ini dilihat dari tulisan siswa dan mahasiswa masih belum banyak dihasilkan dan dipublikasikan. Selain itu, belum ada karya siswa dan mahasiswa di kota Pekalongan yang sederhana dapat dinikmati oleh orang lain dan masyarakat. Hal ini perlu ditindak lanjuti oleh guru dan dosen khususnya yang mengampu pelajaran dan mata kuliah bahasa Indonesia.

Kemudian, metode BATIK (baca, tulis, dan karya) dapat meningkatkan minat siswa dan mahasiswa untuk belajar bahasa Indonesia, dengan menggunakan dan mengenalkan budaya masayarakat pesisir khususnya Pekalongan siswa dan mahasiswa tertarik untuk membaca dan menulis tentang Pekalongan. Tulisan tersebut dapat berupa karya esai, karangan bebas, laporan observasi, laporan perjalanan, cerpen, dongeng, dan cerita rakyat. Hasil karya peserta didik ini dipublikasikan dengan baik oleh guru dan dosen sebagai bahan ajar dalam pembelajaran, sehingga siswa dan mahasiswa tertarik untuk melakukan kegiatan BATIK (baca, tulis dan karya) dalam pembelajaran bahasa Indonesia. Sehingga mendukung terwujudnya Gerakan Literasi Sekolah (GLS).

\section{DAFTAR PUSTAKA}

Abidin, Y., Mulyati, T., \& Yunansyah, H. (2017). Pembelajaran Literasi: Strategi Meningkatkan Kemampuan Literasi Matematika, Sains, Membaca dan Menulis. Jakarta: Bumi Aksara.

Agus, M. (2018). "Rekayasa Perangkat Akuakultur pada Era Revolusi Industri 4.0 sebagai Upaya Inovasi Akademis dalam Perwujudan Kampus Kreati”. Orasi IImiah Dies Natalis XXXVII Universitas Pekalongan. Pekalongan: Unikal Press.

Badan Pusat Statistik. (2016). Kota Pekalongan dalam Angka, Pekalongan Manicipacity in Figures 2016. Pekalongan: BPS Kota Pekalongan.

Disdik. Kota Bandung. (2017). Gerakan Literasi Sekolah. Bandung: Dinas Pendidikan Kota Bandung. (http://disdik.bandung.go.id, diakses Juli 2019).

Eryanto, F. D., Sanjaya, T. Y., \& Noviatika, H. (2018). Buku Berjalan sebagai Solusi Budaya Literasi di SMA Negeri Kota Pekalongan. Pekalongan: Laporan PKM Tahun 2019.

Kustriyono, E., Haryanto, M., \& Setyarum, A. (2018). Pengembangan Metode Batik dalam Mata Kuliah Bahasa Indonesia sebagai Sarana Menumbuhkan Gerakan 
Literasi Mahasiswa (GLM) di Universitas Pekalongan. Pekalongan: Laporan PDP tahun 2018.

Noermanzah, N. (2015). Peran Dosen Bahasa dan Sastra Indonesia dalam Mempertahankan Bahasa Indonesia sebagai Alat Pemersatu Negara Kesatuan Republik Indonesia pada Era Globalisasi. In Prosiding Seminar Nasional Bulan Bahasa 2015. Unit Penerbitan FKIP Universitas Bengkulu, p. 274. http://repository.unib.ac.id/11133/

Noermanzah, N., Abid, S., \& Septaria, S. (2018). Improving the Ability of Writing a Narrative Charge by Using Animated Images Media Student Class V.B SD Negeri 17 Lubuklinggau. BAHTERA: Jurnal Pendidikan Bahasa dan Sastra, 17(2), 116. doi:10.21009/bahtera.172.9 